\title{
APELATIVE ASOCIATE ANTROPONIMELOR ÎN EVOCAREA SENSULUI SACRU VS. PROFAN AL ACESTORA ÎN LIMBA ROMÂNĂ
}

\author{
Margareta Manu Magda \\ Institutul de lingvistică „Iorgu Iordan - Al. Rosetti” \\ al Academiei Române, București, România
}

\section{Appellatives associated with anthroponyms in evoking the latter's sacred vs. profane meaning in Romanian}

\begin{abstract}
The present paper deals with a category of Romanian appellatives which, when associated with specific anthroponyms, recall the original sacred or profane meaning of the respective anthroponyms. More precisely, the study discusses the problem of propositional markers of explicitness, trying to propose, according to various criteria, a framework of classification for these elements on the lexical level of the Romanian language (terms attached to the anthroponyms, referring to the positive vs. negative - spiritual quality of the name bearer, to his/her sociocultural position or institutional function - with sacred vs. profane connotation - in the community, or to the socio-stylistic sphere to which the attached terms belong etc.).

Keywords: appellatives, anthroponyms, (implicit/explicit) meaning/significance, propositional indices vs. presuppositional indices of the sacred or the profane.
\end{abstract}

\section{Preliminarii}

\subsection{Obiectul cercetării}

Lucrarea de față se situează pe linia studiilor care abordează simbolistica (explicită sau implicită) a semnelor lingvistice onomastice, în termenii conceptelor de sacru vs. profan. În acord cu această poziție, se consideră că devenirea umană, în orice plan, este alcătuită, deopotrivă, din activitate conștientă și din experiențe iraționale; se acceptă faptul că omul modern (profan), în calitate de urmaș al lui homo religiosus, păstrează, încă, urme ale comportamentului religios, însă golite de orice semnificație sacră; că acesta are, în subconștient, nostalgia sacrului, fapt care duce, inevitabil, la repetarea neîncetată a unui număr limitat de gesturi și de comportamente fixate în ritualuri; că scenariile inițiatice se păstrează în numeroase fapte și gesturi ale omului areligios din zilele noastre (vezi, de exemplu, cazul atribuirii de nume).

Autoarea va adopta poziția filosofiei culturii, a onomasticii și pragmastilisticii în interpretarea faptelor prezentate. Materialul exemplificator a fost preluat din internet și din texte literare românești publicate. 


\subsection{Considerații teoretice}

1.2.1. O problemă preliminară care se ridică în mod obiectiv, înainte de prezentarea cercetării particulare propriu-zise, anunțate, este definirea sacralităţii, la care este necesar să ne raportăm în paginile de față.

În mod prototipic, sacrul, adjectiv, este definit ca „sfânt” (aparținând transcendentului). În mod curent, însă, el circulă cu accepția mai restrânsă: „cu caracter religios; privitor la religie, care aparține religiei; subst. ceea ce e sacru; sacrul și profanul”. Prin extindere, cuvântul primește sens figurat, însă desacralizat, profan (care ține de imanent): „ fig. foc sacru, entuziasm, geniu; care insuflă un respect oarecum religios”: persoana unui cetățean roman era sacră; se zice despre lucrurile ce nu trebuie divulgate sau atinse: depozit sacru (sursa: Șăineanu, ed. VI, 1929) (apud DEXonline s.v.).

Prin urmare, în asociere cu alți termeni, în primul rând cu acela de profan, cuvântul sacru își extinde sau își restrânge sensul. De asemenea, utilizat conceptual, în contextul diferitelor discipline socioumane, intră în corelație cu alte concepte precum: spațiu, timp, mister, mit, rit, simbol, cuvânt, text, nume etc., nuanțându-şi înțelesul.

1.2.2. Problematica sacrului și a profanului este disputată în prezent, mai mult decât oricând, de pe două poziţii teoretice diferite:

1.2.2.1. Poziția „religioasă” (împărtășită, în primul rând, de adepții filosofiei clasice a religiilor, de teologi și, în cadru instituțional, de slujitorii (practicanți) ai bisericii) ${ }^{1}$, con-

1 - Distincția sacru vs. profan este utilizată într-un mod particular mai întâi în sociologie de către Émile Durkheim 1912. Pentru el, sacrul apare numai în societate și constă dintr-un grup de lucruri, credințe și ritualuri care sunt respectate și adorate (sacre), fiind distincte de toate celelalte aspecte ale vieții sociale, considerate profane. Forța sacrului nu este alta decât forța societății care este anonimă și impersonală, impunându-se individului ca o realitate calitativ superioară. Prin venerarea obiectelor sacre (ca și a imaginii acestora), indivizii, în ultimă instanță, nu își venerează decât propria societate.

- Pentru Rudolf Otto 1917/1992, este importantă nu distincția sacru / profan, ci analiza componentelor raționale și iraționale din cadrul sacrului, ca și a esenței sacrului, a părții pure golite de conținutul etic al categoriei de sacru. Limbajul nu poate decât să sugereze ceea ce depășește experiența naturală a omului, cu ajutorul unor termeni preluați din această experiență.

- La Mircea Eliade 1965/1992, sacrul ține de natura umană și nu de societate, manifestarea sacrului fundamentând ontologic lumea și asigurând, totodată, atributul realității spațiului, timpului și naturii. În mod practic, prima definiție care s-ar putea da sacrului, spune Eliade (1991: 221), este opusul profanului. Profanul este rezultatul unor procese/ schimbări istorice ale comportamentului spiritual, în urma cărora omul modern și-a desacralizat lumea și și-a asumat o existență liberă. Omului modern, într-un cosmos total desacralizat, îi este, prin urmare, din ce în ce mai greu să regăsească dimensiunile existențiale ale omului religios al societăților arhaice.

- În sfârșit, mai recent, Jean-Jacques Wunenburger (2000) definește sacrul drept ansamblul de comportamente individuale și colective care urcă până în timpurile imemoriale. Sacrul implică stări interioare specifice și se obiectivează în fenomene culturale. Wunenburger asociază sacrul cu jocul, considerând că, în societățile tradiționale, jocul și sacrul au avut un scop comun: sondarea adâncimii invizibile a lumii. Acest aspect este, în opinia sa, cea mai bună dovadă $a$ irupției sacrului în profan, dar și a conectării continue a profanului la sacru. Pornind de la interesul crescând pentru ceea ce s-a numit „întoarcerea religiosului”, „moartea și renașterea utopiei” sau 
form căreia ființa lui Dumnezeu este transcendentă radical față de ființa lumii, dar prin energia, lumina sau lucrarea Duhului Sfânt, Dumnezeu este prezent în întreaga creație. Divizarea lumii în două zone distincte, una a fenomenelor sacre și alta a celor profane constituie esența oricarei religii (Morar 2014: 404).

1.2.2.2. Poziția postmodernistă (în toate variantele ei), care lansează conceptul de „Dumnezeu ascuns” (Deus absconditus) și imaginea unei divinități absente sau fără putere în istorie. Autonomia creației, ca rezultat al izolării Divinității în transcendent, a dus, inevitabil, la autonomia omului și a rațiunii umane față de Dumnezeu. Postmoderniștii cer înlocuirea existenței obiectuale prin limbă, text, cunoștințe; aceștia vorbeau și despre necesitatea de a lua în considerare și neraţionalul, inconștientul, existența din activitatea omenească. Neopozitivismul, la rândul lui, vorbește despre cotitura lingvistică din prima treime a secolului XX, despre semiotizarea realității, ce a urmat după aceasta.

Importanța postmodernismului în limbaj constă în accentul pus asupra sensurilor implicite ale cuvintelor și formelor, a structurilor care exprimă puterea.

\subsection{Concepte operaționale}

\subsubsection{Dinamica conceptelor sacru vs. profan prin desacralizare/ resacralizare}

Dinamica enunțării științifice postmoderne se prezintă în forma a două procese diacronice succesive și complementare:

A) o „acţiune demolatoare" a tradiției (postmodernismul revoluționar, critic-subversiv);

B) „o refermecare” a lumii prin valorificarea pluralistă a tradiției (postmodernismul reacționar, neoclasic).

Progresele înregistrate de cercetarea științifică fac realitatea tot mai controlabilă, fapt ce duce la dezvrăjirea lumii, la pierderea semnificației sociale a gândirii, practicii și instituțiilor religioase. Mircea Eliade (1965/ 1992) opina că desacralizarea totală a

„revenirea sacrului”, Jean-Jacques Wunenburger urmărește să pună în evidență experiențele trăite de către omul contemporan ca forme ale unei alternative sacre. El vorbește despre recâștigarea interesului pentru esoteric și științele oculte, despre adeziunea la diverse domenii, precum ecologia, erotismul, spectacolul festin, cultul vedetelor etc., dar și despre o sacralitate conturată în jurul unor fenomene profane și funcționale, cum ar fi noile tehnologii. Impresia care se desprinde de aici este aceea că, în ciuda profețiilor pozitiviste și a lecturilor raționaliste ale modernității, experiența sacrului nu a dispărut, ci mai degrabă a fost deplasată înspre locuri și obiecte noi (vezi, în acest sens, Wunenburger 2000: 42-59 și 112-116).

2 Postmodernismul este termenul de referință aplicat unei vaste game de evoluții în domeniile de teorie critică, filosofie, arhitectură, artă, literatură și cultură. Postmodernismul se ocupă de modul în care autoritatea unor entități ideale (numite metanarațiuni) este slăbită prin procesul de fragmentare, consumism și deconstrucție. Jean-François Lyotard 1984 (https:// ro.wikipedia.org/wiki/Jean-Fran\%C3\%A7ois_Lyotard) a descris acest curent drept o „neîncredere în metanarațiuni”; în viziunea acestuia, postmodernismul atacă ideea unor universalii monolitice (vezi https://ro.wikipedia.org/wiki/Universal_(metafizic\%C4\%83) și în schimb încurajează perspectivele fracturate, fluide și pe cele multiple. 
lumii nu este posibilă, deoarece sacrul se camuflează continuu în profan, de unde și confundarea lui de către omul modern cu profanul. În mod paradoxal, contestarea abuzivă a atitudinii și comportamentului religios nu face decât să favorizeze apariția unor noi modalităţi de manifestare a sacrului.

Pornind de la premisele teoretice prezentate mai sus, putem remarca faptul că, pe baza facultății de cunoaștere, ființa umană sesizează fenomenul revelator în istorie sub chipul unor semne, simboluri menite să trezească, să impulsioneze solicitudinea, respectiv întâlnirea spiritului cu sacrul. Încercuită de percepție, lumea fenomenală mijlocește accesul la spiritualul ascuns sub aparențe temporale. Astfel, prin intermediul ei, subiectul (uman) descoperă, pe de o parte, istoria spirituală a omenirii, iar pe de altă parte, diferența dintre convenționalul ideatic și ideile pure, distincția dintre realitatea temporală și sacru.

Imaginea modernistă a dislocărilor conceptuale din cultura contemporană este una de glisaj permanent a demersului cultural între diferitele ipostaze de auto-întemeiere, între „obiectivismul” impersonal al cunoașterii științifice și „subiectivismul” acțiunii cognitive.

\subsubsection{Semnul onomastic - purtător al spiritului sacru vs. profan}

Unul dintre semnele lingvistice cu o valoare specială, în ansamblul patrimoniului comunicativ uman, este numele propriu (în speță antroponimul). Acest element, spre deosebire de altele, este lipsit de sens în afara actului denominativ de individualizare a unui anumit obiect ${ }^{3}$.

În acest cadru, reamintim că am definit (cu altă ocazie) conceptul lexico-semantic de apelativ, ca unitate de cercetare în antroponimie, pornind de la o bază de definiție funcțională, după două criterii: alocutivitate potențială și funcție deictică. Desemnarea personală se realizează în limba română (după Ionescu 1976) prin trei tipuri de formule de denominație (antroponimică), după calitatea de nume propriu sau comun a elementelor componente: a) formule proprii - constituite din unul sau mai multe nume proprii de persoane sau de locuri (Ion, Nelu, Gheorghiţă, Popescu, Moraru etc.; Ion Ionescu, Calistrat Șchiopu, Petrescu-Dâmbovița, lonescu-Tismana etc.; Ion lonescu de Ia Brad, Niculaie Laie Chioru, Maria Vetii Turcului etc.); b) formule comune - constituite din unul sau mai multe nume comune (tovarășul, domnişoara, primarul, notarul, factorul, profesorul etc.; tovarãş̧ul profesor, domnişoara doctor, primarul orașului etc.; tovarăşul profesor de fizica, soția contabilului întreprinderii etc.); c) formule mixte - constituite din nume comune și propriu (conu Gheorghiţă, domnişoara Popescu, doctorul Petrescu, tovarășul Vasilescu, domnitorul Ioan Cuza, domnitorul Alexandru Ioan Cuza etc.).

În diacronie, între numele propriu și obiectul denumit se stabilește o relaţie

3 Reamintim faptul că apelativul este acea expresie potențial alocutivă, utilizată de un locutor pentru identificarea unei persoane sau a unui grup de persoane; acesta trebuie abordat ca parte integrantă a formulei antroponimice (unitate discursivă prin care se realizează funcția de individualizare și de identificare a membrilor unui grup uman) (v. Ionescu Pérez 2007: 218 219). 
dinamică, dependentă în primul rând de geneza celui dintâi și, în al doilea rând, de contextele situaționale succesive în care semnul funcționează, modificând-şi semnificația (vezi funcționalitatea) în acord cu diferențele de economie, de cultură și de organizare socială, adică de istorie. În planul enunțării științifice, mecanismul în discuție conduce, de cele mai multe ori, la translarea raționamentului științific din lumea sensului în cea $a$ semnificației și, totodată, la încercarea de reconstituire a experienței iraționale, implicitate pe baza semnelor setate în activitatea cotidiană rațională.

\section{Derivația semantică: procesul de desacralizare vs. resacralizare a numelor în diacronie}

\section{1. „Expansiunea” semantic-pragmatică a semnului antroponimic}

În diacronie, semantica termenului sacru cunoaște o evoluție invers proporțională $\mathrm{cu}$ aceea a termenului profan; aceasta se prezintă sub forma unei dezvoltări „scalare” - în expansiune de la sensul-forte (tare) al sacrului și sensul slab al profanului către o imagine slabă a sacrului și una forte a profanului. Același comportament îl regăsim în evoluția corelativă (alunecarea semantică) a semnelor lingvistice (în speță onomastice, denotative) cu cele simbolice (conotative, în speță sacre vs. profane) în diverse stadii denotative vs. conotative, la care ne vom referi în cele ce urmează.

Expansiunea semantică a semnelor onomastice se definește ca un proces treptat, prin care diversele forme nu trec, în mod abrupt, de la o categorie la alta, ci trec, printr-o serie de mici tranziții care tind să fie identice ca tip de evoluție, la nivel universal. Trecerea de la categoriile lexicale la categorii funcționale este dependentă de mediul pragmasemantic în care are loc, respectiv de condițiile sociolingvistice în legătură cu contextele și cu construcțiile care condiționează desacralizarea, respectiv resacralizarea.

Transferul schimbării semantice din domeniul lexical pur și plasarea acesteia în domeniul pragmatic (în care modificările sunt derivate fie prin inferență, fie prin asocierea unor cuvinte cu alte cuvinte în utilizarea lor curentă, fixată în funcție de context) (Joseph 2004: 61) este redat printr-un număr de termeni precum: bleaching, desemanticisation, semantic loss, and weakening; numitorul comun al sensului acestor termeni este acela de „pierdere” (loss). Avem a face, de fapt, cu o redistribuire sau o alunecare, nu o pierdere propriu-zisă de sens (Hopper and Traugott 1993: 84).

Clasa de formule antroponimice vizată ne permite să distinge mai multe etape ale unei cronologii derivaționale.

\subsubsection{Etapa arhaică, originară, a sacrului antroponimic}

Aceasta constă din două variante pe scala glisării de la sacru la profan:

- etapa antroponimică caracterizată prin asocierea cu forma tare a sacrului, vizând numele constitutiv sacre (nume ale divinităţilor, nume de apostoli, sfinți din textele biblice) care își păstrează, în general, statutul nepervertit în cadrul instituționalizat al bisericii (v. termenii creștini Dumnezeu, Isus Cristos, Maica Domnului sau diverse nume de sfinți - apostoli: Petru, Andrei, Ioan, Toma, Bartolomeu etc.); 
Exemple:

(1) Nume constitutive de sfinți (biblice):

Ana: Este unul dintre numele cel mai larg răspândite, atât la noi, cât și în întreaga lume creștină;

Andrei: Sf. Apostol Andrei, „cel dintâi chemat” la propovăduire, este, conform tradiției, și primul care a adus creștinismul pe meleagurile noastre;

Filip: Sf. Apostol Filip din Ierusalim pomenit pe 11 octombrie;

Gavriil: Gavriil apare, în ambele Testamente, drept călăuzitorul spre adevăr și vestitorul ceresc cel mai de seamă al Cuvântului Dumnezeiesc (http://www.crestinortodox.ro/povestea-numelor/ana-71467.html).

- etapa antroponimică originară, caracterizată prin asocierea cu forma slabă $a$ sacrului (sens figurat) cu referire la nume cu semnificație motivată (2a), cunoscută, care se opacizează în timp (fie prin dispariția termenilor sau prin transferul lor dintr-o limbă în alta (2b) etc.).

\section{Exemple:}

(2) a. Nume cu motivație (cunoscută)

Nume de flori: Angela, Angelica - de la Angelica de pădure; Delia - de la Dalie; Dumitrița - denumire populară a crizantemei; Gherghina - o altă denumire a Daliei; Laur, Laura, Laurențiu, Laurian, Lauriana - „dafin”; Liliana, Lilian - de la „liliac” sau de la englezescul Lilly, pentru „crin”; Mălin, Mălina - de la pomul cu același nume; Romaniţa - „mușețel”;

b. Nume străine care își pierd motivația prin transfer: Aleodor este o formă a numelui Eliodor, atestat în Grecia antică în secolele III-II î. Hr. sub forma de Heliodoros, compus la rândul său din Helios „soare” și doron „dar” - „darul Soarelui”, „darul zeului”; Albert, nume de origine francă, este un derivat al termenului Adalbrecht, compus din adäl, „nobil” și beraht, „strălucire” - „faimos, nobil”.

\subsubsection{Etapa mediană, cea a desacralizării parțiale}

Aceasta constă într-un proces de uzură a numelor sacre, pe de-o parte, prin transferul lor în cotidian și, pe de altă parte, prin uitarea (opacizarea) treptată a motivației antroponimelor.

Procesul de „albire” a semnificației sacre primare a unor nume este dublat de un proces de subiectivizare ("subjectification" - v. Traugott 1995: 46), definit, în linii mari, ca dezvoltare a unor expresii suplimentare (apelative potențial alocutive), atașate antroponimului de bază, expresii ce au legătură cu atitudinea sau credința vorbitorului referitoare la ceea ce spune. Subiectivizarea este un proces gradat, prin care forme și construcții care la început exprimă sensuri lexicale primare, concrete și obiective, prin utilizare repetată, în contexte sintactice locale, ajung să servească la îndeplinirea unor funcții tot mai abstracte, pragmatice, interpersonale, bazate pe reacția vorbitorului (cf. Traugott 1995: 32).

Astfel, pentru a evidenția originea divină a personajelor cu nume sacre și a le 
diferenția de muritorii de rând, purtători ai acelorași nume, a fost adoptat un sistem de indici de explicitare ai semnificațiilor implicite, codate în semnele antroponimice arhaice. Acest sistem s-a îmbogățit, în timp, ajungând la o diversificare și complexitate deosebite (în special în mediul bisericesc, unde se justifică pe deplin).

Exemple:

(3) sfânt (cu variante derivaționale sau compuse): Sfântul Vasile cel Mare, Sfântul Serafim de Sarov, Sfântul Ioan Botezatorul, Sfânta Tatiana, Sfânta Nina, Sfântului Antonie cel Mare, Sfântului Marcu al Efesului, Sfântul Clement de Ancira, Sfântul Mucenic Carp, Sfântului Mucenic Nestor;

(4) cuvios: Cuviosul David din Evia, Cuviosul Porfirie din Cavsocalivia;

(5) părinte: Parintele Veniamin Milov, Parintele Victor Ojog, Parintele Acachie Valaamitul, Parintele Cleopa de la Sihastria (http://www.crestinortodox.ro/acatiste/ acatistul-sfantului-vasile-mare-67142.html).

\subsubsection{Etapa desacralizării complete a sensului antroponimelor}

Această etapă coincide cu perioada de maximă dezvoltare a indicilor deictici și potențial alocutivi utilizaţi în scopul explicitării sensurilor ascunse în forme cu devenire istorică și de utilizare masivă a antroponimelor în cadrul unor formule antroponimice adecvate diverselor contexte.

În planul actului comunicativ, se pot distinge două tipuri de indici de descifrare a simbolisticii transcedentale încrustate în semnul onomastic: indici ai implicitării semnificațiilor sacre (presupoziționali) și indici de explicitare (propoziționali) a conotațiilor sacrului.

În paginile de față, ne vom referi la problematica indicilor propoziționali, de explicitare, încercând să schițăm o grilă de clasificare, pe diverse criterii, a respectivelor elemente, în planul lexical al limbii române (termeni, atașați antroponimelor, trimțând la poziția în familie și societate (exprimând relații, funcții profesionale sau politice), la calitatea sufletească - pozitivă vs. negativă - a purtătorului de nume - conotate sacru vs. profan la sfera sociostilistică la care aparțin termenii atașaţi etc.).

Noua viziune se referă la nominație dintr-o dublă optică: cea structurală (din punctul de vedere al poziției în sistem) și cea funcțională (prin care se stabilește raportul dintre sistemul antroponimic, ca dimensiune socială, și interpretarea sistemului, ca dimensiune individuală, relevând rolul vorbitorului în construcția mesajului în cadrul discursului antroponimic) $)^{4}$. Se propune termenul de formulă antroponimică pentru a desemna cazurile în care un morfem $M$, având la origine o valoare semantică $S$ (pe care a putut-o păstra în anumite cazuri de utilizare), dă naştere unui morfem $\mathrm{M}^{\wedge}$ a cărui valoare semantică $S^{\wedge}$ conține o aluzie la utilizarea, în enunțare, a lui $\mathrm{M}^{\wedge}$ cu valoarea $S^{\wedge}$. $\mathrm{M}=\mathrm{M}^{\wedge}$. Trecerea de la $\mathrm{M}$ la $\mathrm{M}^{\wedge}$ este diacronică (aplicată secvențial); $\mathrm{M}$ este o formulă.

4 Pentru tratarea acestor probleme, vezi Miron Fulea 2005, Perez 2007, Felecan (D.) 2011a, b, Felecan (D.) 2014. 


\subsection{Tipuri de formule cu funcție de explicitare în sistemul de denominație românesc}

\subsubsection{Termeni generici}

2.2.1.1. Generice din sfera religioasă (sacre)

Doamne (6a) (< lat. Dǒmìne), Dzeu / Dumnezeul(e) (< lat. dom(i)ne deus) (6b), Părinte (6c), (v. infra și sensurile „tată”, și „preot”), Tată, „Dumnezeu” (6d), Isus Hristos /Fiul lui Dumnezeu (6e), Învățător (6f)/ Sfinți (6g-h).

(6) a. Doamne, curățeaște-mă (CLRV1570: 99).

b. Dumnezeu, cu urechile noastre auzim (CLRV1570: 96).

c. Părinte, blagoslovește! (CLRV1580-91: 107).

d. Tatăl nostru ce ești în ceri, sfințească-se numele tău (CLRV1561: 80).

e. Ce e mie şi ție, Isuse, Fiiule lu Dumnezeu de sus? (CC $\left.{ }^{2} .1581: 416\right)$.

f. Grăiră: „Învățătoare... $\left(C C^{2} .1581: 91\right)$.

g. Bucură-te, stăpână, Fecioară Maria, născătoarea lui Dumnezeu, sprijinitoarea şi ajutătoarea cea grabnică a creştinilor (NÎnv. 1700: 335).

h. Miluiaște-ne, Sfântă Vineri (CLRV1583-1619: 123).

Unele substantive în vocativ din sfera religioasă (Dumnezeule!, Doamne!, Sfinte!), în urma unui proces de derivare delocutivă, capătă valoare interjecțională (Manu Magda 2017a, b).

2.2.1.2. Generice laice arhaice (ca forme de manifestare a sacralității slabe)

A. Formule de reverență

Sistemul de adresare reverențioasă, în special în româna veche, este bogat și variat, atât în forme lexicale, cât și gramaticale. Inventarul cuprinde: denumiri pentru conducătorul statului (considerați unșii lui Dumnezeu): domn/ voc. doamne + pers. 2 sg; împărat/e (și „cu referire la”: vodă/voievod), crai $(7 \mathrm{a}-\mathrm{c})$ sau ranguri în stat sau în biserică (7d-f); pentru funcții și poziții sociale: ban, birău, vistier, stolnic, postelnic etc. $(8 \mathrm{a}-\mathrm{c})$; forme reverențioase de adresare: domn /voc. domnule (pentru „stăpân al pământului, bărbat, orășean, soț, târgoveț”), pan/jupan (<sl. županŭ, „titlu dat în evul mediu, în țările române, celor mai de seamă boieri și dregători”), chir („titlu de politețe, folosit în epoca fanarioților, sec. XVIII și prima jumătate a sec. XIX”; v. DEX online s.v.) (9af), domn/ule (târziu, „formulă generică de adresare politicoasă către bărbați”) ( $9 g)$

(7) a. Doamne împărate, păzeaște-te (FD.1592-1604: 168).

b. Împărate, cade-ți-se să slăvești (FD.1592-1604: 161).

c. Craiule, ce faci? (CLM.1700-50: 285).

d. Boieri, iacătă că... (A.1620: 51).

e. Rogu-mă, svinţi arhierei. (NÎnv. 1700: 215).

f. Şi voi, egumeni şi preoți şi alţi frați câți vă aflați întru Hristos, toți, iar vă rog...

(NÎnv. 1700: 241).

(8) a. Bane Mihalcio şi tu, vistiiar Stoico, dau-vă în ştire (DÎ XXXI 1600). 
b. Aşişjdere şi voi părcălabi şi globnici şi deşugubinari (DIR.A.IV,260: 207-208). c. Închinăciune (...) dumneata pârcălabe de Bistrița şi dumneata, birăule tot de acolo (PH.1500-10: 779).

(9) a. DOMNe, rog DOMNetale se... (DÎ C 1594).

b. Vouă, iarăşi, domnilor şi boierilor ai acestei crăii, poruncesc (CLM.1700-502: 93).

c. O, doamnă, împărăteasă şi stăpână. (NÎnv. 1700: 219).

d. Să știi, jupâne, că... (Sind.1703: 260).

e. Pan Udrea, ghetmanu i pârcălabu Suča(v)skii, (DÎ CX 1600).

f. Cinstite părintele mieu, chir Macarie. (NÎnv. 1700: 241).

g. Domnilor, domnilor ai cinstitului Maghistrat (IS: 49-50).

Sistemul de adresare reverențioasă, în curs de constituire în textele secolului al XVI-lea, prezintă forme lexicale și gramaticale instabile: măria ta (10a) în adresare directă pentru domnitor/ conducător; sfinția ta (10b) pentru adresarea către fețele bisericești; forme precum boiari dumnevoastră (10c) pentru nobili, majoritatea dispărute în româna modernă.

(10) a. Aşa să şti<i>, Măria ta (Dî, XCIII 1593).

b. Aşea socotescu, părinte, Svințiia ta, (Cron.1689,II: 69).

c. Boiari dumnevoastră şi fraților, ceşti bătrâni şi ceşti tineri, de vom greşi (NÎnv. 1700: 285).

\subsubsection{Termeni de adresare generici (ancorați în cotidian) ${ }^{5}$}

2.2.3.1. Termeni de adresare protocolari

Aceștia sunt identificați în funcție de statutul social și relațiile de rol dintre interlocutori, sugerând „respect”, „deferență”:

a) generici literari (domnule / doamnă / domnișoară, duduie), asociați sau nu cu nume de familie, cu funcția sau cu titlu (Domnule [inspector]);

b) onorifici: Altețea voastră, Majestate, Excelența sa, regina Margareta;

În raport cu nivelul de formalitate a contextului de comunicare, se înregistrează o gradare a elementelor fatice. Formele protocolare de adresare, asociate cu forme verbale de persoana a II-a plural + termeni exprimând o apreciere subiectivă a relațiilor dintre interlocutori (drag, iubit, onorat, scump, stimat), sunt specifice anumitor contexte comunicative mai mult sau mai puțin formale: - mediului academic: Ilustrissime Rector, Stimați colegi, Onorată asistență - mass-mediei sau conferințelor: Stimați (tele)spectatori, dragi / Stimați ascultători, Onorat auditoriu, Dragi colegi;

c) termeni desemnând numele de funcții (președinte, primar, ministru), ocupații (inginer, maistru, colonel, general), titluri profesionale (doctor, academician).

5 Româna dispune de un sistem al elementelor de adresare puternic diferențiat, care cuprinde sistemul pronominal, sistemul termenilor de adresare și interjecțiile de interpelare (cf. Manu Magda în GALR 2008, II: 843-857). Vezi și Manu Magda în GR 2013: 590-598 și SOR 2016: 618-629. 
2.2.3.1. Termeni de adresare familiari

A. Desemnând nume de rudenie cu utilizare generică: mamă/ tată/tataie/frate/ soră (11)

Termenii din această categorie au ca trăsătură semantică pertinentă „legătura” fundamentală și indestructibilă cu universul creator, ocrotitor, intim. Exemple:

(11) Povestea condimentată a lu' „Tata” lu' Mama Manu, shaormeria cunoscută de toți clujenii. (https://www.ziardecluj.ro/povestea-condimentata-lu-tata-lu-mama-manu-shaormeria-cunoscuta- de-toti-clujenii)

Mama Zina, Zina Dumitrescu (născută Zenobia Bogoș) a fost o creatoare de modă din România, numită de manechinele și colegii din show-biz „mama modei din România”. (https://ro.wikipedia.org/wiki/Zina_Dumitrescu)

Mama Omida a fost o vrăjitoare celebră de etnie romă . În prezent, Mama Omida este sinonim cu „o persoană care știe tot, având puterea de a prezice viitorul!”

(www.einformativ.ro/ce-inseamna-mama-omida-_q1037.html)

Muzica creștină - fratele Dinescu (http://m.trilulilu.ro/muzica-crestina-fratele-dinescufocul-tau- asculta)

„Rugați-vă pentru fratele Alexandru! Roagă-te şi tu, cititorule, căci numele nu priveşte doar pe comandantul trupelor victorioase [...], ci îi priveşte pe toți ceilalți ...

(www.humanitas.ro/humanitas/rugati-va-pentru-fratele-alexandru)

B. Desemnând termeni de adresare generici, specifici anumitor comunități:

(12) a. Baba Vanga a fost o prezicătoare oarbă bulgară.

(https://ro.wikipedia.org/wiki/Baba_Vanga).

b. In folclorul slav, Baba Yaga are mai multe durabile atribute: este capabil de a vrăji, zboară într-un mortar, trăiește în pădure într-o colibă.

(https://www.tpu.ro/timp.../imi-spune-si-mie-cineva-poveste-cu-baba-yaga-multumesc/).

c. Vezi profilurile persoanelor care poartă numele de Baba Rada. Inscrie-te pe Facebook pentru a lua legătura cu Baba Rada şi cu alții. (https://ro-ro.facebook.com/public/ Baba-Rada).

d. Moș Vasile, Moș Vasile, iar a dat bordura-n tine!

(www.vremeanoua.ro/mos-vasile-mos-vasile-iar-a-dat-bordura-n-tine).

a) Generice familiare, potențial alocutive

În adresarea familiară sunt utilizate foarte frecvent denumirile specifice date de comunitate diferitelor grade de rudenie pentru exprimarea unor relații ocazionale, întâmplătoare (sugerând vulgaritate, lipsă de respect): mamă!, tată!, bunico!, bunicule!, unchiule!, mătuşă!, nepoate!, vere!, tanti! sau nene! (unele dintre acestea, pragmatizate). Exemple:

(13) Interlopul craiovean Iulian Preda, fost Chiriță, fost Țurcan, zis „Tataie“, „Cap“ sau "Giuliano", a fost arestat preventiv pentru 30 de zile

(http://adevarul.ro/news/eveniment/reteta-interlopului--craiovean-tataie-facutmilion-euro- proxenetism-eu-vin-acolo-frate-fac-cascavalu-1_569d060537115986c $6 \mathrm{a} 33 \mathrm{bc} 7 /$ index.html). 
Apoi, când el nu a mai fost, mamaie Tanța, cum îi ziceam eu, nu s-a gândit nicio clipă să-și refacă viața (www.formula-as.ro> Arhiva > Anul $2015>$ Numarul $1179>$ Asul de inima). Hai mamaie la „facultate”! Trăiască Bill Gates și al său Word cu autocorector! Ne-a izbăvit pe toți de efortul inutil al învățării scrisului corect... (lexpaticus.blogspot.com/2013/07/ hai-mamaie-la- facultatae.html).

Unde stai, tataie? / Dom' doctor, departe. (TDM III: 950).

„Săru' mâna, tanti!” /„Bună, nene Tică”. (TDM III: 750).

Pe măsură ce distanța dintre roluri se reduce, vorbitorul recurge la vocativul numelor proprii sau al substantivelor comune, pronume și chiar la interjecții:

b) Termeni de adresare constitutiv alocutive (interjecții de adresare): Bre, fă, bă, măi:

(14) „Hai bre şefule, da ş-am făcut? Eu îs chior? Io sun la tieleviziuni, sun la ... (www.b1.ro > Ştiri $>$ Auto).

Hai,bre,Cola,cefacemaici?zosoblog(https://www.zoso.ro/hai-bre-cola-ce-facem-aici/) Fă, Doino, uite c-au început s-apară şi veşti bune! | Mircea Morariu (adevarul.ro/news/ politica/fadoina-uite-c--inceput--s--apara...1.../index.html)

Cristii!!! Bă Cristi!! Cheamă-l bă pe Cristi!!! | Bețiv Vs

(https://www.youtube.com/watch?v=JuYJFpJGZwE)

\subsubsection{Expresii familiare non-alocutive: tiparul (Det) $\mathbf{N}_{1} \mathbf{D E} \mathbf{N}_{2}$}

„Analiza tiparului (Det) $\mathrm{N}_{1} \mathrm{DE} \mathrm{N}_{2}$ în plan discursiv al limbii, conduce la constatarea că modelul de construcție stă sub semnul manifestării atitudinii subiective a emițătorului, realizările lui fiind considerate sintagme puternic marcate afectiv. Mai mult decât atât, s-a spus de cele mai multe ori despre elementul de pe prima poziție că presupune o caracterizare subiectivă a referentului și că este purtătorul unei predicații de calificare depreciativă cel mai adesea (apreciere ironică, blamare, insultă, injurie)" (Mihail 2009: 1).

Această structură vizează numai referenții animați și actualizează pe prima poziție substantive sau adjective substantivizate care vehiculează atitudini de insultă sau afecțiune (afurisitul/ mincinosul/ tăntălăul de Mihai, un nebun de inventator, fraiera de soră-mea, o urâtă de fată, un iscusit de ziarist, frumuşica de Ioana, bietul/sărmanul/săracul/nefericitul de profesor) (Ibidem: 2).

(15) Da' bleaga de Ivona, ea cu serviciu, ea cu prietinile, cu țigarea-n gură şi cu cafelile (Adameșteanu 1997: 27).

Dacă nebunu ăsta de vatman porneşte acu? (Adameșteanu 1997: 31).

A umblat ea mult ca să nu rămâie cu zbanghia de Ivona piatră-n casă (Adameşteanu 1997: 41).

Scrisoare deschisă de la prostul de mine către "deșteptul” de Moise Guran (blog.naie. ro/?p=96).

Primarul Iașului către George Scripcaru: „Când deșteptul de Mazăre şi cu ăla de la 
Braşov scoteau tramvaiele, noi dezvoltam infrastructura de ... (brasovromania.net > Brasov Romania).

idioata de Eba a fost consiliată de cei 24 de consilieri personali cu Eminescu la Bruxelles ... (https://www.youtube.com/watch?v=27yHqVuJIl8).

22 feb. 2011 - Coruptul de Vornicu pe când va fi închis, el a împărțit, probabil, anii cheltuiți de Anton cu facturile suspecte (www.sandrinio.ro/brigada-diverse/ fostul-prefect-cusnir-albit-de-dna).

Caragiale Ion Luca - 2016 - Fiction

Măndica (sunând prelungit): Ce slugi dobitoace! (Feciorul vine.)/ Măndica: Nu te-am chemat pe ... unde e dobitoaca de Roza? Ce face cu ceaiul? (https://books.google.ro/ books?isbn=6066000500).

Câteva runde cu Florica, ceva i-a șoptit intriganta de Sonia și acum ne reproșază că nu-i suntem recunoscători pentru calculatorul dat cândva lui A. (https://books.google.ro/ books?isbn=6066680757).

Se remarcă faptul că (Ibidem: 3 ) există o componentă livrescă a realizărilor construcției, actualizată mai ales în literatură și în limba standard, și o componentă familiarargotică, foarte expresivă, prezentă în limbajul cotidian, în presă și în internet, uneori strict dependentă de datele „de ultimă oră” ale contextului cultural, politic și social.

\section{Considerații finale}

Analizând formulele antroponimice din limba română actuală, am constatat o mare disponibilitate în direcția construirii unor sintagme dintre cele mai diverse ca rezultat al unui proces diacronic de derivare semantică corelativ cu dispoziția scalară a sacrului și profanului la nivelul semnificației semnului antroponimic (de la explicit la implicit și de la sacralitate tare la sacralitate din ce în ce ma slabă).

Diversele componente potențial alocutive, asociate semnului antroponimic (simplu), sunt menite să suplinească sensurile implicite, încrustate în semnele antroponimice primare, caracterizate prin sacralitate explicită, tare.

La nivelul utilizărilor din româna actuală, semnul antroponimic complex (dezvoltat) este foarte fecvent, fapt ce constituie o dovadă a productivității structuriilor explicite de marcare a sacrului (prin translarea semnificațiilor din plan semantic în plan sintactic). Fenomenul are consecințe și la nivelul sistemului gramatical, contribuind la conturarea unei preferințe pentru structurile analitice ca purtătoare ale semnificțiilor lingvistice.

\section{Surse ${ }^{6}$}

Adameşteanu, G. 1997. Dimineață pierdută. Bucureşti: Editura 100+1 Gramar.

A.1620 = Alexandria. Bucharest: Ed. F. Zgraon. Fundația Națională pentru Ştiință şi Artă, 2005 (Cele mai vechi cărţi populare în literatura română, 11). (South Transylvania, Braşov or Hațeg) $\mathrm{CC}^{2} .1581$ = Coresi, Evanghelie cu învățătură. Ed. S. Puşcariu, Al. Procopovici: Diaconul Coresi, Carte cu invățătură (1581), vol. I, Textul, Bucharest: Socec, 1914. (Braşov)

\footnotetext{
6 Pentru textele de literatură veche, citate, vezi SOR 2016, cap.13, Corpus.
} 
CLM.1700-502 = Miron Costin. Letopisețul Țărâi Moldovei. Ed.: M. Costin. Opere. ed. P. P. Panaitescu. Bucharest: Editura de Stat pentru Literatură și Artă, 1958. p. 41-201. (Moldova)

CLRV = Al. Mareş. Crestomația limbii române vechi, I (1521-1639). Bucharest: Editura Academiei Române.1994.

Cron.1689 = Cronograftradus din greceşte de Pătraşco Danovici, ed. G. Ştrempel, 2 vols. Bucharest: Minerva, 1998. p. 3-271 (vol. I); 5-380 (vol. II). (Moldova)

DIR.A = Documente privind istoria României, veacul XVII. A. Moldova. Bucharest: Editura Academiei (1612); 1956: IV (1616-20); 1957: V (1621-5). (Moldova)

DÎ = Documente şi însemnări româneşti din secolul al XVI-lea, text stabilit şi indice de Gh. Chivu, M. Georgescu, M. Ioniță, Al. Mareş, Al. Roman-Moraru. Bucharest: Editura Academiei Române. 1979.

FD.1592-1604 = Floarea darurilor. Ed. Alexandra Roman Moraru, Bucharest: Minerva, 1996 (Cele mai vechi cărți populare în literatura română, 1), 119-82. (Moldova, Putna Monastery)

IS = Nicolae Iorga. Scrisori de boieri. Scrisori de domni, ediția a II-a. Vălenii-de-Munte: Datina românească. 1925. P. 49-110, 131-41, 254-311.

NÎnv. 1700 = Învățăturile lui Neagoe Basarab către fiul său Teodosie. Ed. F. Moisil, D. Zamfirescu. Bucharest: Minerva. 1971. P.125-352. (Wallachia, Bucharest)

PH.1500-10 = Psaltirea Hurmuzaki. ed. I. Gheție and M. Teodorescu. Bucharest: Editura Academiei Române. 2005. (Moldova)

Sind.1703 = Sindipa. Ed. M. Georgescu. Bucharest: Minerva. 1996 (Cele mai vechi cărți populare în literatura română, 1). P. 249-315. (Braşov)

TDM III = Texte dialectale Muntenia, III. 1987/1993. Publicate de Costin Bratu, et al. Bucureşti: Editura Academiei.

\section{Bibliografie}

Durkheim, É. 1912. Les formes elementaires de la vie religieuse. Paris: Quadrige, PUF.

Eliade, M. 1965/1991. Mituri, vise şi mistere. În Eseuri. Bucureşti: E. Ştiințifică.

Eliade, M. 1992. Sacrul şi profanul. Bucureşti: E. Humanitas. https://gawrylyta.files.wordpress. com/2011/10/sacrul-si-profanul-eliade.pdf (accesat în septembrie 2017).

Felecan, D. 2011a. O categorie de apelative neconvenționale recente: numele comune atribuite persoanelor feminine din domeniul showbizului românesc. În Confluențe lingvistice și filologice. Omagiu profesorului Nicolae Felecan la implinirea a 70 de ani, O. Felecan, D. Felecan (coord.), 235-250. Cluj-Napoca: Editura Mega.

Felecan, D. 2011b. Observaţii privind utilizarea unor alocutive de identificare în limba româna actuală (exemplul Președintelui României). În ONOMASTICON. Studii despre nume și numire I, O. Felecan (ed.), 277-295. Cluj-Napoca: Mega.

Felecan, D. 2014. Pragmatica numelui și a numirii neconvenționale: de la paradigme teoretice la practici discursive. Cluj-Napoca: Editura Mega, Argonaut.

GALR 2008 = Guțu Romalo, V. (coord.). Gramatica limbii române, I-II. Bucureşti: Editura Academiei Române, tiraj nou, revizuit.

GR 2013 = Pană Dindelegan, G. (ed.). The Grammar of Romanian. Oxford: Oxford University Press.

Hopper, Paul J. and Closs Traugot, Elizabeth. 2003 (1993). Gammaticalization. Cambridge: Cambridge University Press. 
Ionescu, C. 1976. Observații asupra sistemului antroponimic românesc. LR 25: 519-528.

Ionescu Perez, P. C. 2007. Concepte, metodologie și terminologie în antroponimia romanică. În Limba română, limbă romanică. Omagiu acad. Marius Sala la împlinirea a 75 de ani, S. Reinheimer Rîpeanu, I. Vintilă-Rădulescu (coord.), 215-234. București: Editura Academiei Române.

Joseph, J. E..2004. Language and Identity: National, Ethnic, Religious. Houndmills, Basingstoke, Hampshire \& New York: Palgrave Macmillan.

Lyotard, J.-F. 1979. La condition postmoderne. Paris: Éditions de Minuit.

Manu Magda, M. 2008. Limba română vorbită. În GALR 2008, II: 843-857.

Manu Magda, M. 2013. Vocative phrases and address. În GR 2013: 590-598.

Manu Magda, M. 2016. Appellation and forms of address. În SOR 2016: 618-629.

Manu Magda, M. 2017a. Gramatică și pragmatică. Un studiu de caz: interjecția Doamne în limba română. În Sintaxa ca mod de a fi. Omagiu doamnei profesoare Gabriela Pană Dindelegan, la aniversare, A. Dragomirescu et al. (eds.), 265-277. București: Editura Universității din București.

Manu Magda, M. 2017b. Interjecția în texte vechi românești (2 versiuni). Diacronia 6, A93-A93. diacronia.ro.

Miron-Fulea, M. 2005. Nume proprii. Interfața semantică-sintaxă. București: Editura Universității din Bucureşti.

Morar, Nicolae. 2014. Sacrul în viziunea lui Nicolae Steinhardt. În Text şi discurs religios, VI, Secțiunea Literatura și sacrul, 403-412. Iași: Editura Universității „Alexandru Ioan Cuza.”

Otto, R. 1917/1992. Sacrul. Despre elementul iraţional din ideea divinului şi despre relaţia lui cu raționalul. Cluj-Napoca: E. Dacia.

SOR = Pană Dindelegan, G. (ed.). 2016. The Syntax of Old Romanian. Oxford: Oxford University Press.

Traugott Closs, E. 1995. The role of the development of discourse markers in a theory of grammaticalization. În Paper presented at the 12th International Conference on Historical Linguistics. University of Manchester.

Wunenburger, J.-J. 2000. Sacrul. Cluj-Napoca: Editura Dacia. 